\title{
'n Tydige simposium oor die Groot Trek en die Slag van Bloedrivier
}

\author{
PIETER MÖLLER \\ Noordwes-Universiteit
}

Simposium: Die slag van Bloedrivier en die nalatenskap daarvan: verskillende perspektiewe. Aangebied deur die Erfenisstigting, 13 en 14 Oktober 2006, WNNR-Konferensiesentrum, Lynnwood, Pretoria.

Die simposium is geopen deur Dr. Willem Cruywagen, die voorsitter van die Erfenisstiging se direksie. Hy het die nagenoeg 150 simposiumgangers daarop gewys dat dit noodsaaklik geword het dat die Afrikanergesinde ook moet kennis neem van ander bevolkingsgroepe se kulture en hul sieninge en interpretasie van historiese gebeure . Dit beteken nie noodwendig dat die Afrikanergesinde sy eie sieninge moet prysgee nie.

Die eerste referaat is gelewer deur Dr. Jan Visagie, (Stellenbosch), waarin hy na enkele perspektiewe op die oorsprong en oorsake van die Groot Trek verwys het. Hierna het Prof. H.C. (Jatti) Bredekamp (HUB Iziko Museums) 'n terugblik gegee ten opsigte van die Slawevrystellingskwessie en die Groot Trek.

Prof. Marius Swart (Port Elizabeth) het 'n referaat van die gebeure in Natal voor die Slag van Bloedrivier, insluitende die bestaan en impak van die Retief-Dingane-traktaat, gelewer. Hy het hoofsaaklik die Afrikanerperspektief gestel.

Dr. Jackie Grobler (UP) het 'n oorsig van die verloop van die Slag van Bloedrivier gegee waarin hy hoofsaaklik die Afkikanerperspektief gegee het, maar aangesien Prof. Mathenjwa, Voorsitter van die Voortrekkermuseumraad (PMB), nie vir die simposium opgedaag het nie het hy ook oorsigtelik verwys na die Zulu-perspektiek oor die aanloop tot en Slag van Bloedrivier, en die verloop en gevolge van die slag. 
Na middagete het Prof. Piet Strauss (UOVS) gepraat oor die aflegging van die Gelofte; inhoud en bindingskrag daarvan en oor die saak rakende Goddelike ingryping tydens die slag.

Dr. J. Jacobs (Direktoraat Pta), Krygshistorikus het gewys op hoedanig strategiese en taktiese beslissings die Slag van Bloedrivier bepaal het.

Me Alana Bailey, (SA Vereniging vir Kultuurgeskiedenis), het insigte weergegee waarin sy verwys het na hoe en deur wie Geloftedag deur die jare gevier is. Sy het veral ook verwys na die anderskleuriges se benadering.

Saterdagoggend het die Dekaan van die fakulteit Krygskunde (US) by Saldanha, Prof. Edna van Harte in die plek van Dr. Wally Serote (Freedom Park Trust), 'n referaat gelewer oor die plek van 16 Desember as deel van ons nasionale erfenis, en veral gewys op versoening wat bewerkstellig moet word.

Mnr. Flip Buys (Solidariteit) het verwys na die deelname van verskillende groepe aan die nasiebou- en versoeningsaktiwiteite en redes gegee waarom gesamentlike deelname nie spontaan plaasvind nie. Hy het dit onomwonde gestel dat die huidige regering in die geskiedenis sal moet verantwoording doen deurdat hulle dikwels nie demokraties optree teenoor minderheidsgroepe in die land nie.

Hierna het verskeie jongmense, skoliere sowel as studente, hul indrukke gegee van die jeug se sieninge rakende die Groot Trek en die Slag van Bloedrivier. Hulle bydrae was baie positief deur die simposiumgangers ontvang.

$\mathrm{Na}$ afloop van die simposium het generaal Gert Opperman

Hoof Uitvoerende Beampte, Voortrekkermonument of Erfenisstigting, indrukke rakende die simposium sy indrukke van die samesprekings weergegee. ${ }^{1}$

Na my mening is die volgende aspekte waarna Opperman verwys het van belang.

1. Dat daar nie noodwendig konsensus oor alle aspekte bereik is nie, maar dat die simposium nietemin allerweë as 'n uiters tydige en suksesvolle simposium beskou is.

2. Opperman beweer dat dit inderdaad die bedoeling was dat daar tydens die simposium van verskillende sieninge kennis geneem sou word, dat verskille genoteer kon word, dit deurgepraat kon word, en, waar nodig, wedersydse vasklou aan mites en dwalings uitgewys kon word. Daarom is dit baie jammer dat van die Swart sprekers op 'n baie laat stadium onttrek het en ook nie hulle

1 Hierdie inligting is hoofsaaklik verkry van 'n dokument wat van generaal Gert Opperman ontvang is na afloop van die simposium. 
referate vir voordrag beskikbaar gestel het nie. Hulle teenwoordigheid en deelname sou waarskynlik nog groter legitimiteit en relevansie aan die simposium verleen het.

Aspekte waaroor daar volgens Opperman wel redelike konsensus tydens die simposium verkry is, is onder andere;

1. dat daar in 'n land soos Suid-Afrika, wat 'n groot verskeidenheid kultuurgroepe verteenwoordig, 'n verskeidenheid van interpretasies en weergawes van ons geskiedenis sal wees.

2. Daar moet altyd binne die geskiedskrywing ruimte gelaat word vir verskillende perspektiewe. Behoorlike navorsing, wat aan die basiese beginsels van die historiese metode voldoen, moet die grondslag hiervan wees. Hierdie perspektiewe moet egter altyd volgens die korrekte tydgees beoordeel word. Opperman wys tereg daarop dat daar tydens die besprekingsessies gedurende die simposium groot klem daarop gelê is dat daarteen gewaak moet word dat persone met hul eie agendas nie die geskiedenis vir eie gewin probeer rekonstrueer nie en dat oordrewe, ongefundeerde regstellende sieninge, nie op 'n ongegronde wyse tot selfs groter verdraaiings en onwaarhede lei nie.

3. Bestaande paradigmas moet aan die hand van nuwe feite en perspektiewe getoets word. Dit is egter baie belangrik dat dit deel van 'n voortdurende proses moet wees. Eie standpunte moet aangepas word en waar nodig moet meer standpunte, ook in eie geledere, geakkommodeer word. Opperman beklemtoon dat daar by die skryf van die geskiedenis van die Groot Trek reg moet geskied aan alle groepe en is van mening dat die gees van samewerking wat in Piet Retief se manifes voorkom, opnuut aandag verdien. Hy wys ook daarop dat Retief se manifes 'n belangrike dokument vir versoening verteenwoordig.

4. 'n Volgende aspek wat na my mening baie belangrik is, en waarna Opperman ook verwys, is dat gebeure in die konteks van die tyd beoordeel moet word. Om huidiglik, na afloop van meer as 170 jaar, die hedendaagse norme (byvoorbeeld t.o.v menseregte) in isolasie en buite verband te gebruik vir die beoordeling van die destydse situasie, sal nie realisties en billik wees nie. Opperman wys daarop dat daar nietemin gepoog moet word om sodanige gebeure in die hede te kontekstualiseer. Sodoende kan 'n sinvolle projeksie gemaak word van hoe daar in die toekoms te werk gegaan behoort te word. Hy beklemtoon dat die opkomende geslagte 'n deurslaggewende rol hierin sal moet vertolk.

5. 'n Volgende belangrike konsensuspunt wat bereik is en waarna Opperman tereg verwys, is dat in die beoordeling van die gebeure rakende die Slag van Bloedrivier ons moet aanvaar dat daar beide 
'n objektiewe (feitelike) en subjektiewe (persepsiële en geloofskomponent teenwoordig is. Die eerste kan aan die hand van wetenskaplike navorsing redelik bewys word. Die kwessie van Goddelike ingryping kan op geloofsgronde aanvaar word maar dit kan beswaarlik op menslike grondslag bewys of op ander afgedwing word. Daarteenoor is dit die goeie reg van almal wat dit in die geloof aanvaar en daarmee wil assosieer, om dit ook in die praktyk só te betuig en te gedenk.

6. Opperman verwys na Kolonel Jakes Jacobs se aanbieding en is korrek in sy siening dat benewens die kwessie van moontlike Goddelike ingryping, daar ook goeie gronde is om die uitslag van die Slag van Bloedrivier aan die hand van normale krygsnorme te verduidelik, waaronder die keuse van die slagveld, die gebruik van meerderwaardige wapentuig, vuurkrag en beweeglikheid, die staat van sielkundige voorbereiding, gesindheid, dissipline en geduld van die opponerende gevegsmagte en die effek van klimatologiese toestande ens.

7. Daar is in die verlede misbruik gemaak van Dingaans- en Geloftefeeste om ander doeleindes te bereik, maar ons moet waak om foute van die verlede nie te herhaal nie. Dit is aanvaarbaar dat die herdenking van 16 Desember as 'n Sabbatdag gevier word, mits dit op die beginsel van vrywillige deelname geskied. Dit mag ook 'n dag wees waartydens daar gewerk word aan nasiebou en versoeningsaktiwiteite. Politieke en ideologiese motiewe mag egter nooit ter sprake wees nie, aangesien daar dan eerder spanning en onverdraagsaamheid bewerkstellig sal word.

8. Nasiebou moet konstruktief nagestreef word en daar moet voortdurend pogings aangewend moet word om versoening te bewerkstellig tot voordeel van opkomende geslagte.

9. Die jeug se bydrae is van kardinale belang en hulle sal met oortuiging en entoesiasme moet deel raak van hul eie geskiedenis.

10. By die simposium kon daar nie tot 'n finale slotsom gekom word nie aangesien daar deurgaans met 'n voortgesette en dinamiese proses gewerk word. Verdere besinning en dialoog is noodsaaklik in die toekoms. Die simposium was tog 'n belangrike stap in die regte rigting. 